\author{
KATARZYNA SMOLIŃSKA, JOANNA JANCZ, \\ AGATA PRZEMIENIECKA, KATARZYNA KUPRIANIEC \\ Poznań
}

\title{
Stan poinformowania polskiego społeczeństwa oraz rola politycznego zaangażowania w świetle akcesji Polski do Unii Europejskiej
}

\begin{abstract}
Wstęp
Zjawisko polityczne, jakim było wstappienie Polski do Unii Europejskiej budziło dużo, różnych emocji i wywołało sekwencję celowych działań. Przed zorganizowaniem referendum akcesyjnego społeczeństwo musiało zostać odpowiednio poinformowane o korzyściach i konsekwencjach akcesji Polski do UE. Referendum akcesyjne w Polsce miało charakter wiążący i decydowało o tym, czy Polska wstapi do Unii Europejskiej ${ }^{1}$. W związku z tym, społeczeństwo musiało zostać dobrze przygotowane na ten krok. Docelowo pożądanym stanem był wzrost zaangażowania politycznego i świadomości politycznej polskiego społeczeństwa. W związku z tym, iż poziom kultury politycznej wyraźnie przekłada się na zaangażowanie polityczne i społeczne obywateli istniała obawa, że niski poziom społecznego zainteresowania kwestiami politycznymi może niekorzystnie wpłynąć na proces integracji Polski z Unią, a niedoinformowanie społeczeństwa o korzyściach powodować mogłoby negatywną ocenę integracji. Akcesja Polski do UE stanowiła więc moment, w którym obywatele powinni zainteresować się politycznymi problemami, tym samym miało to mieć wpływ na frekwencję w referendum akcesyjnym.

Polska wstąpiła do Unii Europejskiej w 2004 r., co wprowadziło wiele zmian w kraju. Od tego momentu minęło 8 lat. To odpowiedni czas, by przeanalizować, jak społeczeństwo ocenia swoją decyzję i jakie realne korzyści przyniosła nam akcesja, a jakie koszty zmuszeni byliśmy ponieść.
\end{abstract}

\section{Negocjacje Polski z UE}

Negocjacje akcesyjne stały się jednym z najważniejszych etapów integracji Polski z UE. To w ich trakcie miały zostać określone warunki na jakich Polska miałaby uczestniczyć w strukturach europejskich. Przebieg negocjacji akcesyjnych między Polską a Unią Europejską, decyzja o rozpoczęciu przez Unię Europejską negocjacji akcesyjnych z pięcioma państwami Europy Środkowej i Wschodniej (Czechami, Estonią,

1 J. Barcz, E. Kawecka-Wyrzykowska, K. Michałowska-Gorywoda, Integracja europejska, Warszawa 2007, s. 65. 
Polską, Słowenią i Węgrami) oraz z Cyprem zapadła na posiedzeniu Rady Europejskiej w Luksemburgu 13 grudnia 1997 r. Jej podstawą jednakże była wcześniejsza rekomendacja zawarta w Opiniach Komisji Europejskiej (Avis) z 16 lipca 1997 r. na temat złożonych przez te państwa wniosków członkowskich oraz stosowny raport Prezydencji dla Rady ${ }^{2}$. Oficjalną datą rozpoczęcia negocjacji był 31 marca 1998 r. W tym celu powołano 37 podzespołów zadaniowych, które odpowiadały za opracowanie stanowisk w poszczególnych obszarach. Przewodniczącymi Polskiego Zespołu Negocjacyjnego (PZN) byli: w latach 1997-2001 - Jacek Saryusz Wolski oraz w latach 2001-2004 - Danuta Hübner. W całym przebiegu negocjacji akcesyjnych Polski do UE wyróżnić można pięć znaczących etapów. Pierwszym z nich był screening, czyli dwustronny i wielostronny przegląd ustawodawstwa pod kątem jego zgodności z prawem UE (acquis communautaire). Screening rozpoczął się 27 kwietnia 1998 r. i zakończył 5 listopada 1999 r. Następnie miało miejsce formułowanie stanowisk negocjacyjnych tworzonych przez Grupę Roboczą ds. Negocjacji i zatwierdzanych przez RM. Po ich ustaleniu wymieniano informacje, co miało prowadzić do uzgodnienia stanowiska negocjacyjnego i porozumienia. Gdy obie strony znały już stanowiska negocjacyjne, czyli pozycje wyjściowe, wówczas można było otworzyć dany obszar negocjacyjny. Ostateczne zamknięcie negocjacji nastąpiło 13 grudnia 2002 r. Ostatnim etapem negocjacji było uzgodnienie treści Traktatu Akcesyjnego. Traktat Akcesyjny podlegał zatwierdzeniu i przyjęciu absolutną większością głosów przez PE (9 kwietnia 2003 r.) oraz jednogłośnie przez Radę UE (14 kwietnia 2003 r.). Traktat wszedł w życie po zakończeniu unijnej procedury ratyfikacyjnej. W Polsce proces jego przyjęcia odbywał się w formie ogólnonarodowego referendum w dniach 7-8 czerwca 2003 r., w którym Polacy opowiedzieli się za przystąpieniem do struktur europejskich. Warto jednak zwrócić uwagę na nastroje społeczne towarzyszące procesom negocjacji. Same negocjacje kojarzą się Polakom raczej z rozmową oraz ustępstwami i dawaniem czegoś za coś, niż uporem, sprytem, walką i grą ${ }^{3}$. Wyraźnie widoczne stało się więc zjawisko depersonalizacji negocjacji, tzn. Polacy nie ufali rządowi oraz działaniom poszczególnych osób. Wyjątkowo istotny był stosunek do ekipy politycznej rządzącej krajem, ponieważ w znacznym stopniu wpływał on na stosunek społeczeństwa do integracji europejskiej. Istotnym czynnikiem, również bezpośrednio wpływającym na postawy społeczeństwa była wyjątkowo wyrazista debata publiczna, podczas której politycy przedstawiali efekty negocjacji oraz konsekwencje integracji z Unią, w odniesieniu do interesów państwa oraz poszczególnych grup społecznych. Spotkania jednak wzbudzały liczne kontrowersje, bowiem nie tylko nie dostarczały definicji na temat nowej, trudnej do zinterpretowania sytuacji, ale także wzbudzały niechęć do problematyki związanej z dostosowaniem polskich standardów do unijnych oraz pozycji Polski i Polaków w zjednoczonej Europie. Cały proces negocjacji rozpatrywany był w kategoriach przyspieszenia, spowolnienia lub zaniechania. Wybór któregoś z tych punktów odniesienia zależał od bilansowania korzyści i kosztów w świadomości społecznej. Okazało się, iż najczęściej popierano opcję spowolnienia. Zwolennicy tej kategorii uważali, że nego-

2 K. Lastawski, Historia integracji europejskiej, Toruń 2006, s. 22.

3 J. Grzelak, D. Maison, G. Wąsowicz-Kuryło, Kultura negocjacyjna w kontekście negocjacji akcesyjnych, Warszawa 2000, s. 45-46. 
cjacje w sprawie członkostwa Polska powinna podjać dopiero po zakończeniu przemian ekonomiczno-gospodarczych w kraju, a nawet po osiagnięciu standardów najbogatszych państw Unii. Proces negocjacji przebiegać miał, według nich, w znacznie wydłużonym czasie politycznym.

Jednocześnie zauważyć można było wzrost pozytywnych opinii społecznych w ocenie procesu integracji i negocjacji w sprawie członkostwa. Wynikało to ze wzrostu przekonania wśród Polaków, że poszerzenie UE o nasz kraj będzie korzystne zarówno dla Unii, jak i dla Polski (26\%). Takie podejście cechuje społeczeństwa o wysokim stopniu stabilizacji społecznej. Wskazywano także na to, iż proces integracji z UE jest najkorzystniejszym rozwiązaniem dla rozwoju kraju, w przeciwieństwie do bliższej integracji chociażby z USA czy z Rosją. Warto dodać, że w listopadzie 2001 r. większość oceniających wyraziła zaufanie do prac zespołu negocjacyjnego kierowanego przez ministra Jana Kołakowskiego. W opiniach tych osób dominowało przekonanie, że w swych pracach negocjatorzy kierują się interesem całego społeczeństwa. Niektórzy jedynie twierdzili, że ich działania będą podporządkowane partiom politycznym. Obawiano się bowiem upolitycznienia tego procesu. Już w 2002 r. większość, bo aż 64\% oceniła zdecydowanie negatywnie działania negocjatorów. Jako argument podawano, iż negocjatorzy mogli osiagnąć zdecydowanie lepsze warunki dla Polski. Dopiero po wystapieniu premiera RP podającego ostateczny wynik negocjacji nastroje społeczne uległy poprawie. Twierdzono, iż w obecnej sytuacji gospodarczej naszego kraju nie można było wynegocjować lepszych warunków. Pogląd ten był charakterystyczny zarówno dla zwolenników SLD-UP, jak i PO. Deklarowano też akceptację i pozytywne odczucia „na myśl o bliskim wejściu Polski do Unii Europejskiej”, większość zaś osób uważała proces negocjacji, jak i samą perspektywę wejścia Polski do UE, za wielki sukces naszego kraju.

\section{Sytuacja społeczno-gospodarcza w Polsce i Europie przed akcesją}

Planowane przystapienie Polski do UE wywołać miało nie tylko istotne zmiany na gruncie politycznym czy gospodarczym. Pociągało to za sobą również zmiany w nastrojach społecznych. Jednym z warunków przystapienia do UE, jakie Polska musiała spełnić było zbliżanie istniejącego i przyszłego ustawodawstwa do prawa europejskiego, co zresztą zostało zrealizowane 1.02.1994 r., gdy wszedł w życie Układ Europejski ustanawiający Stowarzyszenie między Rzeczpospolitą Polską z jednej strony, a Wspólnotami Europejskimi i ich państwami członkowskimi, z drugiej strony. Poza tym jednak istotne było stworzenie właściwych ram dla stopniowej integracji Polski ze Wspólnota, zwłaszcza poprzez popieranie rozwoju handlu ${ }^{4}$ i harmonijnych stosunków gospodarczych między Polską a Wspólnotami Europejskimi. Jednakże stan polskiej gospodarki przed akcesją do UE nie zapowiadał się obiecująco. Dla polskiego handlu zagranicznego rok 1998 zamknął się deficytem w wysokości 18,9 mld USD. W porównaniu z rokiem poprzednim zwiększył się on o 13,8\%. Na taki bilans handlu zagranicznego miał przede wszystkim wpływ wysoki i realnie rosnący kurs złotego, który niekorzystnie

\footnotetext{
4 Z. Puślecki, Proces integracji ekonomicznej Polski z Uniq Europejska, Poznań 2001, s. 21.
} 
oddziaływał na eksport oraz zwiększał import. Polskie produkty przegrywały na rynku rosyjskim konkurencję z wysoko subsydiowanymi produktami z krajów UE i Stanów Zjednoczonych. Dodatkowo rynek rosyjski zaczął poszukiwać towarów według zasady „dobre i tanie”, co również ograniczyło możliwości eksportowe.

Zastrzeżenia i zalecenia ze strony UE dotyczyły także rolnictwa jako tego sektora gospodarki, który wymaga wzmożonych wysiłków ze strony polskiej. Użytki rolne w Polsce zajmują 18,5 mln ha, co stanowi 59\% ogólnej powierzchni kraju. Pod względem obszaru użytków rolnych Polska znajduje się na III miejscu w Europie, po Francji i Hiszpanii. Wskaźnikiem obrazującym poziom rozwoju gospodarczego kraju jest udział rolnictwa w tworzeniu produktu krajowego brutto (PKB). Udział polskiego sektora rolnego w tworzeniu PKB jest nadal znaczący, choć od początku transformacji znacznie się zmniejszył z 11,8\% w 1989 r. do 6\% w 1996 r., 5,1\% w 1997 r. i 4,9\% w 1998 r. Niestety, struktura gospodarstw rolnych w Polsce jest niekorzystna. W 1998 r. nadal dominowały małe gospodarstwa do 5 ha, stanowiąc ponad 56,4\% ogółu gospodarstw.

W związku z tym pojawiły się niemal natychmiast pytania płynące ze strony społeczeństwa polskiego: czy polska gospodarka sprosta konkurencji na rynku europejskim? I czy jesteśmy dostatecznie przygotowani do członkostwa w UE? Obawa czy sprostamy wymaganiom europejskim odbijała się na nastrojach społecznych. Polacy wyrażali największy niepokój w związku z podporządkowaniem gospodarki celom zewnętrznym. Stąd przeciwnicy akcesji Polski do UE wymieniali również obawy na gruncie ekonomicznym, obejmowały one wiele polskich przedsiębiorstw ${ }^{5}$, które na skutek zbyt silnej konkurencji zagranicznej mogłyby upaść lub ograniczyć produkcję. Rynek polski po zlikwidowaniu ceł, mógłby zostać zalany tanimi produktami z wysokorozwiniętych krajów członkowskich, które dotują rodzimą produkcję. Według sceptyków stalibyśmy się rynkiem zbytu dla różnych towarów, których jakość jest o wiele niższa od jakości produktów znajdujących się na rynkach Europy Zachodniej. Te obawy nie ominęły również rolnictwa. Wyrażano niezadowolenie ze zdolności rozwojowych, cen polskich gruntów ornych, struktury obszarowej, poziomu wsparcia i ochrony rolnictwa, poziomu wykształcenia, ale także kondycji psychicznej polskich rolników ${ }^{6}$, z których, według danych GUS, w 1996 r. jedynie 17\% respondentów odpowiedziało, że ich gospodarstwa mają szanse rozwoju. Dominowały jednakże postawy typu zachowawczego, brak optymizmu i niechęć do ryzyka. Obawiano się, że po uzyskaniu członkostwa polscy rolnicy będą mieli mniejsze, w stosunku do rolników unijnych, szanse sprostania konkurencji i utrzymania się na rynku produktów rolnych. Wśród rolników opinię taką wyrażała znaczna większość (84\%). Wyraźnie jednak ujawniały się nadzieje na spadek bezrobocia, a także szybszy wzrost gospodarczy, jak i łatwiejszy dostęp do europejskiego rynku pracy.

Obawy jednak dosięgnęły także życia materialnego Polaków po akcesji. Wskazywano na wzrost kosztów utrzymania oraz cen większości towarów i usług, głównie cen s. 91.

A. Doliwa-Klepacka, Z. M. Doliwa-Klepacki, Członkostwo Unii Europejskiej, Białystok 2008,

${ }^{6}$ W. Puliński, Polityka rolna Unii Europejskiej, w: Integracja europejska, red. A. Marszałek, Łódź 1997, s. 51. 
żywności. Taki pesymizm wyrażali głównie rolnicy, emeryci, osoby o niskim dochodzie i wykształceniu podstawowym ${ }^{7}$. Pesymistycznie nastawione do integracji pozostawały kobiety obawiające się przede wszystkim pogorszenia warunków materialnych życia, jak i wzrostu cen. Natomiast większy optymizm przejawiali mężczyźni, ludzie młodzi, z wykształceniem średnim lub wyższym, wśród nich właściciele firm, kadra kierownicza i inteligencja. Konsekwencje przystapienia do UE rozpatrywano w kategoriach nadziei lub obaw. I tak, materialne warunki życia oraz praca po akcesji, w opinii jednych miały się polepszyć, przez innych wskazywane jako obszar, co do którego dominuje obawa ${ }^{8}$. O zdrowiu Polacy myśleli przede wszystkim w kategoriach obaw przed jego pogorszeniem. Nadzieje Polaków wiązały się w głównej mierze z poprawą funkcjonowania systemu politycznego i gospodarczego w naszym kraju, ale również wskazywano na możliwość ugruntowania się postaw proekonomicznych i korzystne zmiany w stosunkach międzyludzkich. Zwolennicy wejścia do UE wyrażali nadzieję, zaciekawienie, ale i obawę, podczas gdy przeciwnicy, przerażenie, smutek, a nawet rozgoryczenie. Niestety, perspektywa członkostwa w Unii często nadal budziła w polskim społeczeństwie uczucia negatywne.

\section{Analiza przedakcesyjnych broszur i kampanii informacyjnych}

W maju 2003 r. do wszystkich gospodarstw domowych w Polsce została rozesłana broszura, w której podjęto próbę odpowiedzi na zasadnicze pytania i wątpliwości społeczeństwa polskiego związane z członkostwem w UE. Podano w niej adresy stron internetowych: prezydenta RP, portalu rządowego, portalu UKIE, Przedstawicielstwa Komisji Europejskiej w Polsce i innych instytucji zajmujących się integracją europejską. Pod koniec kwietnia do wszystkich gazet ogólnopolskich dołączono płytę CD zawierającą wystapienie prezydenta RP, hymny Polski i Unii Europejskiej, tekst Traktatu Akcesyjnego, bilans kosztów i korzyści członkostwa Polski w UE, opis struktury i zasad funkcjonowania UE, był to największy krok w stronę informowania społeczeństwa polskiego o UE.

Oprócz informacji dostarczanych wprost do domów, organizowano m.in. programy edukacyjne, kampanie informacyjne oraz kolportowano ulotki do szkół i innych placówek publicznych. Prowadzono również akcje informacyjne w hipermarketach. $\mathrm{W}$ zgromadzonych materiałach z tamtego okresu możemy znaleźć m.in. Przewodnik dla obywateli oraz informator Konstytucja dla Europy. Dobre źródło informacji stanowiły ulotki wydane przez Urząd Komitetu Integracji Europejskiej. Były one częścią przedakcesyjnej kampanii informacyjnej. W ulotkach możemy znaleźć adresy wszystkich Regionalnych Centrów Informacji Europejskiej w Polsce, historię integracji ówczesnych Wspólnot Europejskich, źródła prawa UE, szczegółowo opisane swobody wspólnego rynku UE, informacje o wzajemnym uznawaniu dyplomów i kwalifikacji zawodowych w krajach członkowskich Unii Europejskiej, ale także zostały opisane

${ }^{7}$ L. Kolerska-Boblińska, Przed referendum europejskim - absencja, sprzeciw, poparcie, Warszawa 2003 , s. 89.

${ }^{8}$ Ibidem, s. 90. 
możliwości podejmowania pracy przez obywateli polskich w krajach UE. Informatory i ulotki można ocenić jako dobrze opisujące kompetencje poszczególnych instytucji Unijnych, polityki realizowane w ramach Unii, zasady i podstawowe prawa jej funkcjonowania. Jak wynika z powyższego, dostarczanie informacji obywatelom stanowiło wysoki priorytet.

Należy również zaznaczyć, iż kampanie informacyjne były licznie organizowane na terenie całego kraju przez różne ośrodki promocyjne ${ }^{9}$. Jednak do najszerszego grona odbiorców informacji, dotarły programy i reklamy telewizyjne na temat członkostwa Polski w Unii. Była to zdecydowana większość społeczeństwa (83\%).

\section{Przedakcesyjny stosunek mediów do UE}

Polskie media - szczególnie telewizja - mimo teoretycznie zakładanej obiektywności w przygotowywaniu spotów informacyjnych, podzieliły się na stacje „za” Unią Europejską i na te „przeciw” Unii Europejskiej ${ }^{10}$.

Najmniej obiektywny charakter miały spoty informacyjne telewizji publicznej, ponieważ akcesja Polski do UE była wtedy priorytetem rządowym. Pierwsze newsy dotyczyły zawsze sukcesów na drodze do wstapienia do UE, obiektywnie błahe i mniej ważne informacje podawane były w bardzo obrazowy sposób, jeśli tylko dotyczyły pozytywnych stron akcesji. Przeważały hasła jedności w obliczu wstapienia do UE, zawieszenia konfliktów partyjnych, ale także pojawiały się szeroko omawiane informacje dotyczące korzyści wynikających z przynależności do UE. Stacja TVP dominowała pod względem ilości i czasu wyświetlania spotów kampanii informacyjnych o UE.

Prywatne stacje telewizyjne - TVN i Polsat - wyświetlały newsy informacyjne o podobnym charakterze do tych z telewizji publicznej. Gorącymi informacjami zawsze były komunikaty pozytywne, poszczególne sukcesy na drodze Polski do UE. Różnicą było przedstawianie opozycji. Jeżeli miało miejsce wydarzenie negatywne, np. porażka strony rządzącej na pewnym etapie akcesyjnym, przedstawiane to było jako skuteczny sabotaż opozycyjny, rzadko kiedy jako rzeczywistą porażkę rządzących.

Przeciwko akcesji do UE było Radio Maryja, chociaż na forum ogólnopolskim starało się przybierać pozycję neutralną. W wypowiedziach księży prowadzących audycje zauważyć można było pewną dozę zachowawczości: „To nieprawda, że Radio Maryja jest przeciwko Europie czy przeciwko Unii Europejskiej. Tak do końca nie jest. Natomiast prawda jest taka, że Radio Maryja jako ośrodek wolny i niezależny chce służyć Bogu, Kościołowi i polskiemu narodowi, bo ten naród to radio utrzymuje. [...] postanowiliśmy żeby dać możliwość wypowiedzenia się również i tym, którzy inaczej myślą, znają fakty, inaczej je oceniają, żeby każdy z nas, zanim pójdzie do referendum miał

9 M.in. były to: Kampania Biura Pełnomocnika Rządu ds. Referendum Europejskiego, Kampania Urzędu Komitetu Integracji Europejskiej, Kampania Prezydenta RP, Kampania Inicjatywy Obywatelskiej TAK w referendum, Kampania Polskiej Fundacji im. Roberta Schumana, Kampania Ruchu Obywatelskiego Karta Przyszłości.

${ }^{10}$ Analiza oparta na przeglądzie dostępnych w Internecie archiwalnych wydań spotów informacyjnych poszczególnych stacji telewizyjnych. 
pełną informację o tym czym ta Unia jest, na jakich warunkach Polska ma do Unii wchodzić" $"$. Negatywne nastawienie rozgłośni do akcesji można było zauważyć u osób zapraszanych w tamtym okresie. Wśród gości - przeważali politycy Ligi Polskich Rodzin, która stała w opozycji wobec przystąpienia Polski do Unii Europejskiej.

\section{Przedakcesyjny stosunek partii politycznych do UE}

Głównymi przeciwnikami integracji Polski z Unią Europejską była: Liga Polskich Rodzin, Ruch Katolicko-Narodowy oraz Unia Polityki Realnej. Argumenty LPR opierały się o stwierdzenie, że rolnicy dostaną mniejsze dotacje, niż sugeruje rząd. Ponadto sprzeciwiali się „,kolejnym rozbiorom Polski i jej kolonizacji” ${ }^{\prime 2}$. Argumenty partii były mocno narodowościowe, oscylowały głównie wokół hasła, że nie oddadzą państwa polskiego ani polskiej narodowości. Sugerowano także szybki rozpad UE. UPR z Korwinem-Mikke na czele propagowała hasło: Unia Europejska - Nie, Europa - Tak. Argumentami przeciwko integracji Polski z UE były między innymi: napływ imigrantów do Polski, zablokowanie przez UE rozwoju gospodarczego Polski poprzez regulacje prawne, brak partnerskiego nastawienia niektórych państw członkowskich, chcących zdominować inne kraje. Natomiast Antoni Macierewicz, ówczesny przedstawiciel Koła Poselskiego Ruchu Katolicko-Narodowego skomentował rządową informację na temat traktatu akcesyjnego mówiąc, że informacja ta nie przedstawiła żadnego sposobu na obronę stanowiska, że rząd nie licytował traktatu „,w dół”. Oznaczało to, że rząd nie odparł fundamentalnego zarzutu. Nawet $\mathrm{w}$ ramach negocjacji nie poczynił takiego wysiłku, jaki poczyniły swego czasu Dania, Irlandia, Malta. Krótko mówiąc, nie walczył o polskie interesy narodowe. Szedł od kompromisu do kompromitacji i kapitulował. Najlepszym symbolem tego są dwa fakty. Po pierwsze - na czele negocjatorów postawiono ludzi z dawnej służby bezpieczeństwa. Nie było premiera, nie było prezydenta ani innych ministrów. Był pan Truszczyński, który reprezentuje Polskę jako dawny współpracownik służb bezpieczeństwa. Druga kwestia - dzisiejsza poranna wypowiedź pana Grabowskiego z Rady Polityki Pieniężnej. W Radiu Zet oświadczył, że „aby zebrać pieniądze na składkę dla UE, trzeba będzie ciąć wydatki i sięgnąć do kieszeni podatników. I to jest prawda o UE. To jest zły traktat, złe warunki. Aby naprawdę myśleć o uzyskaniu przez Polskę właściwego miejsca w Europie, trzeba ten traktat odrzucié"13.

Stanowisko niejednoznaczne przyjęło Polskie Stronnictwo Ludowe, a także Samoobrona, uzależniając swoje poparcie dla UE bądź też jego brak od sytuacji, w jakiej znajdą się polscy rolnicy po akcesji.

Wśród polityków popierających integrację Polski z Unią Europejską przeważały głównie komentarze Leszka Millera: „Polska poza Unią Europejską, to kraj drugiej

11 Radio Maryja, audycja Refleksje po szczycie UE w Kopenhadze, 24.12.2002, http://www.radiomaryja.pl.eu.org/nagrania/20021223-krol/20021223-krol.html.

12 P. Rybarczyk, LPR przeciwko wejściu Polski do UE, 1.05.2004, http://wiadomosci.wp.pl/kat,1342,title,LPR-przeciwko-wejsciu-Polski-doUE,wid,5206594,wiadomosc.html?ticaid=1e7ff\&_ticrsn=3.

${ }_{13}$ M. Goss, Sejm niemy. Postowie będa głosować nad przyjęciem rzadowej informacji o traktacie akcesyjnym po jego podpisaniu w Atenach, „Nasz Dziennik”, 17.06.2012, http://www.naszawitryna.pl/europa_771.html. 
kategorii skazany na życie na marginesie i powolny rozwój gospodarczy"14. Głównymi argumentami obozu zwolenników akcesji (SLD, UP, PO, PIS) był rozwój gospodarczy Polski, możliwość inwestowania w Polsce przez zagranicznych przedsiębiorców, co otworzy rynek pracy, swoboda poruszania się i studiowania.

W trakcie samej debaty za integracją opowiedziały się kluby SLD, UP, PO, SKL i PiS. Zdecydowanie przeciwko akcesji były: Samoobrona, LPR i kluby poselskie Porozumienia Polskiego oraz Ruchu Katolicko-Narodowego.

\section{Analiza informacji na poziomie lokalnym}

Przed wejściem do Unii Europejskiej wielu Polaków prezentowało odmienne oceny dotyczące również przyszłego rozwoju ich najbliższej, małej „ojczyzny”, czyli gminy. Jak już wyżej wspomniano, grupą wyrażającą największe obawy, i to zarówno w perspektywie kraju, jak i na poziomie lokalnym, byli właśnie rolnicy. Owe obawy przyjmowały podobny wymiar zarówno w sferze ogólnokrajowej, jak i w wymiarze samorządu lokalnego. Warto jednak bliższej przyjrzeć się oczekiwaniom, jakie stawiano na poziomie lokalnym w związku z wejściem Polski do UE. Pierwszym, podstawowym aspektem i sugerowaną korzyścią była możliwość pozyskania środków finansowych z UE, wspomagający w sposób znaczący dalszy rozwój gmin, powiatów i województw oraz inwestycji w tych obszarach. Ważna okazała się także możliwość współpracy z zagranicznymi partnerami, głównie przy realizacji projektów o charakterze transgranicznym. Oczekiwania wiązały się również z wszechstronną promocją własnej gminy, a także szeroko pojętą wymianą kulturalną i gospodarczą, promocją turystyki, współpracy w zakresie budowy wspólnej infrastruktury, wymianą informacji oraz wspólnymi szkoleniami ${ }^{15}$.

Niestety w większości przeważała opinia, iż żadna gmina, powiat czy województwo bez odpowiedniego wsparcia finansowego nie będzie się odpowiednio rozwijać. W związku z pojawiającymi się wciąż nowymi obawami, powołano tzw. Gminne Centra Informacji. Jest to placówka działająca w sposób kompleksowy, umożliwiająca społeczności lokalnej dostęp do nowoczesnych technologii przekazu informacji, mająca wpływ na rozwój inicjatyw lokalnych oraz promująca przedsiębiorstwa działające w regionie. W GCI można uzyskać informacje na temat Programów pomocowych UE, funduszy przedakcesyjnych, polityce strukturalnej UE, ułatwieniach podatkowych, prawie pracy UE, otwartych konkursach, przetargach czy przeciwdziałaniu bezrobociu. GCI jest skierowane głównie do osób bezrobotnych, chcących podnieść swoje kwalifikacje, przedsiębiorców czy pragnących założyć własną działalność. Niestety, ogromna większość społeczeństwa (80\%) przyznaje się, że nie wie, gdzie w jej gminie znajduje się takowe Centrum. O lokalizacji Punktu Informacji Europejskiej w swojej gminie wiedzą przede wszystkim mieszkańcy najmniejszych (do 20 tys.) miast. Orientacja w tej sprawie jest tym lepsza, im wyższe wykształcenie ankietowanych oraz im

14 Kto głosuje przeciw UE, skazuje Polskę na byt drugiej kategorii, PaM za Onet.pl, 22.04.2003, http://www.ppr.pl/artykul-quot-kto-glosuje-przeciw-ue-skazuje-polske-na-byt-dru-53678-dzial-13.php.

A. Lutrzykowski, Samorzad terytorialny, ale jaki?, Toruń 2009, s. 169. 
większe zainteresowanie polityką. Co ważne, tylko 14\% osób, które orientują się w lokalizacji Punktu Informacji Europejskiej w ich gminie, deklaruje korzystanie z niego - poszukiwanie tam informacji na temat UE. Zdecydowana większość - $85 \%$ badanych, którzy wiedzą gdzie mieści się PIE, nie usiłowała się w nim niczego dowiadywać.

\section{Referendum akcesyjne}

Referendum krajowe w sprawie akcesji Polski do Unii Europejskiej odbyło się w dniach 7-8 czerwca 2003 r. Według oficjalnych danych Państwowej Komisji Wyborczej frekwencja wyniosła 58,85\%, tj. do głosowania przystapiło 17586215 osób spośród 29868474 uprawnionych do głosowania. Przedmiotem referendum było wstapienie Polski do Unii Europejskiej i przyjęcie traktatu ateńskiego. Postawiono wyborcom pytanie: „Czy wyraża Pan/Pani zgodę na przystąpienie Polski do Unii Europejskiej?”. Odpowiedź „TAK” udzieliło 77,45\% z głosujących, czyli dokładnie 13516612 osób. Tylko 22,55\% z nich, tj. 3936012 odpowiedziało „NIE”. Referendum zostało uznane za ważne przez Sąd Najwyższy ${ }^{16}$.

Uzyskana liczba głosów „na tak” najwyższa była w województwach: śląskim (1 927 221), mazowieckim (1 764 733), wielkopolskim (1 201760 ), natomiast ilość głosujących przeciwko akcesji w województwie Mazowieckim (612 599) ${ }^{17}$. W obwodach zagranicznych największa (100\% frekwencja) zaistniała w Królestwie Belgii (Antwerpia), Republice Bułgarii, Republice Chile (Wyspa Króla Jerzego) i w mieście Tajpej. W tamtejszych ośrodkach wyborczych łącznie oddano 1460 głosów „na tak” i tylko 48 głosów przeciwko ${ }^{18}$.

\section{Opinie Polaków przed referendum - na podstawie badań TNS OBOP 10-12.05.2003 r.}

To istotne badanie, gdyż zostało zrealizowane na miesiąc przed referendum, tym samym było ostatnim badaniem opinii społecznej przed tym wydarzeniem. Na podstawie danych, w maju mniej więcej na równi rozłożyły się głosy między osobami czującymi się dobrze poinformowanymi o kwestiach związanych z członkostwem Polski w Unii Europejskiej (48\%), a tymi, którzy mieli poczucie odwrotne (46\%). Dodatkowo, 57\% respondentów zadeklarowało swój udział w referendum, z czego 74\% wyraziło chęć poparcia członkostwa Polski w UE, a 16\% opowiedziało swój sprzeciw ${ }^{19}$.

Badani Polacy najbardziej pośród korzyści z wstappienia do UE, cenili sobie swobodę podróżowania, mobilności pracy oraz kwestie związane z ochroną środowiska. Najbardziej obawiano się wzrostu cen dóbr.

16 Państwowa Komisja Wyborcza, Referendum ogólnokrajowe w sprawie wyrażenia zgody na ratyfikacje Traktatu dotyczqcego przystapienia Rzeczypospolitej Polskiej do Unii Europejskiej, 7.06.2012, www.referendum2003.pkw.gov.pl.

17 Ibidem.

18 Ibidem.

19 TNS OBOP, Polacy o członkostwie Polski w Unii Europejskiej przed referendum, Warszawa 2003, http://www.obop.pl/archive-report/id/1420, 6.06.2012. 


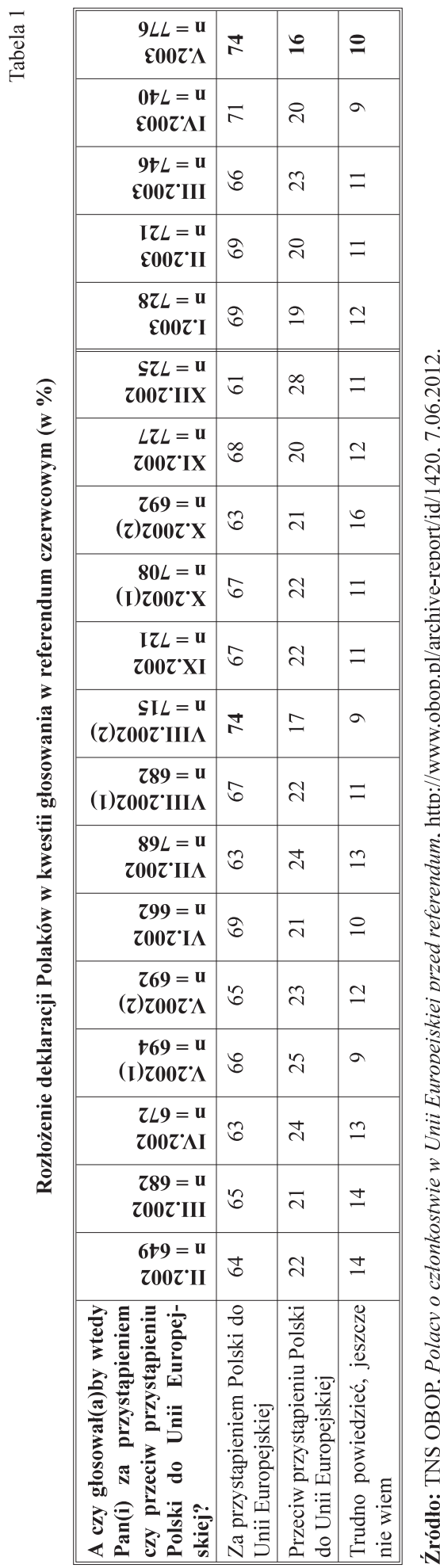


Analizując poczucie społeczeństwa o propagowaniu informacji związanych z członkostwem Polski w UE, można wywnioskować, iż w większości badań sondażowych, poczucie poinformowania wzrastało, natomiast poczucie jego braku stopniowo malało, a w ostatnim sondażu po raz pierwszy spadło poniżej $50 \%$.

Stan poinformowania społeczeństwa o UE, tuż przed referendum akcesyjnym, wyraźnie pokazuje badanie OBOP, mianowicie sprawdzano czy dotarły do respondentów jakiekolwiek materiały dotyczące akcesji. Blisko $70 \%$ badanych miało kontakt z takimi materiałami. Najczęściej były to broszury i dalej według częstotliwości wskazań: plakaty, informatory, książki, płyty CD i raporty ${ }^{20}$. Potwierdzenie dostępności materiałów informacyjnych wskazuje, że działania kampanii informacyjnej znacznie zwiększyły poczucie odpowiedniego poinformowania społeczeństwa o UE ${ }^{21}$.

Warto również przeanalizować tabelę obrazującą deklarację zagłosowania na „tak” lub „nie” dla członkostwa Polski w UE.

Wśród respondentów deklarujących zagłosowanie na „tak” w referendum, wyniki na przestrzeni miesięcy rozkładały się podobnie, oscylując średnio wokół 66-69\%. Przy czym dwa razy przekroczyły próg $70 \%$. Wraz z w miarę stabilną chęcią poparcia członkostwa w UE, malała liczba osób deklarujących głosowanie na „nie”. Mieszkańcy miast, dobrze wykształceni, zainteresowani sprawami politycznymi, czujący stabilność finansową chętniej opowiadali się za członkostwem w UE. Miejsce zamieszkania znacznie nie wpłynęło na stopień wyrażania poparcia dla członkostwa oraz stopnia poczucia poinformowania o kwestiach związanych z członkostwem w UE.

\section{Polacy wobec czlonkostwa w UE po referendum - badania TBS OBOP sierpień 2003 r.}

Z wyników badań ponad 50\% Polaków uznaje, iż członkostwo w UE przyniesie korzyści, $17 \%$ respondentów obawia się, że akcesja przyniesie coś złego. Niestety tylko $36 \%$ badanych twierdziła, iż Polska jest przygotowana do członkostwa, przy czym sami nie będziemy w stanie spełnić zobowiązań, a 28\% negatywnie ocenia nasz kraj zarówno pod względem przygotowania jak i możliwości dotrzymania zobowiązań ${ }^{22}$. Dodatkowo widoczny był duży wskaźnik nadziei Polaków na poprawę sytuacji w kraju w perspektywie długoterminowej - $71 \%$. Jednak biorąc pod uwagę opinie dotyczące bliższej perspektywy czasowej, wyniki są pesymistyczne. Aż 34\% Polaków nie dostrzega nadziei na poprawę sytuacji, a 39\% nie dostrzega możliwości niesionych przez $\mathrm{UE}^{23}$.

Powyższe badanie zostało przeprowadzone w oparciu o trzy wskaźniki: ogólnej percepcji członkostwa, oceny przygotowania Polski do członkostwa oraz możliwości

${ }^{20}$ Społeczny bilans korzyści i kosztów członkostwa Polski w Unii Europejskiej, red. E. Skotnicka-Illasiewicz, Urząd Komitetu Integracji Europejskiej, Departament Analiz Ekonomicznych i Społecznych, Warszawa 2003, s. 72.

${ }^{21}$ Ibidem.

22 Ibidem, s. 73.

23 Ibidem. 
realizowania zobowiązań i po trzecie prognozowany wpływ, który akcesja do UE może wywrzeć na: życie osobiste, sytuację kraju w perspektywie najbliższych lat oraz perspektywie długoterminowej ${ }^{24}$.

Wykres 1. Jak oceniono czlonkostwo Polski w UE. Będzie czymś dobrym, czy zlym?

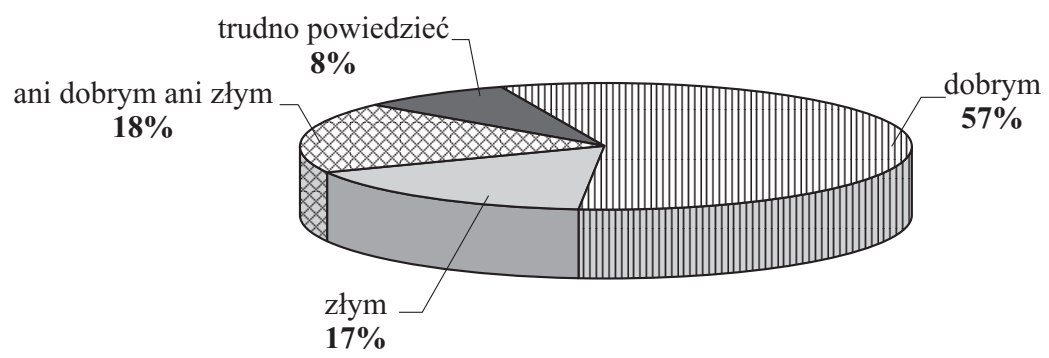

Źródło: na podstawie TNS OBOP, Opinie o członkostwie w Unii Europejskiej na poczatku sierpnia 2003, http:/www.obop.pl/archive-report/id/1460, 8.06.2012.

Podobnie, jak w badaniu przed referendum, optymistyczne wybrzmienie padało z ust osób lepiej wykształconych oraz mieszkańców miast zainteresowanych sprawami politycznymi. Co ciekawe równie chętnie i optymistycznie wypowiadały się osoby młode $\mathrm{w}$ tym nastolatkowie, dodatkowo w grupie tej znaleźli się także zwolennicy PO oraz SLD ${ }^{25}$.

Z najnowszych badań przeprowadzonych przez TNS OBOP na początku roku 2012 wynika, iż 56\% badanych pozytywnie ocenia członkostwo Polski w UE, a tylko 11\% negatywnie. Dodatkowo 29\% badanych ma ambiwalentne odczucia. Co równie istotne, ponad połowa badanych - 54\% ma pojęcie o tym, co dzieje się w UE - prezydencja Polski, definiowanie prezydencji, przewodnictwa w UE. Należy podkreślić fakt, iż 53\% respondentów uważa, iż pozostałe państwa UE nie liczą się z Polską, tak jak powinni ${ }^{26}$.

\section{Analiza poczucia bezpieczeństwa i stabilności kraju}

Bezpieczeństwo, a zatem stan poczucia braku zagrożenia w Polskiej historii ma wielorakie znaczenie. W ramach badanego zjawiska należy podkreślić fakt transformacji systemowej, co zapoczątkowało wiele zmian. Centrum Badania Opinii Społecznej zajmuje się również monitorowaniem poczucia bezpieczeństwa w kraju. Badania są przeprowadzane w oparciu o ankietę zawierająca pytanie: „Czy Pani/Pana zdaniem Polska jest krajem, w którym żyje się bezpiecznie?"27. Jeszcze w 2000 roku 70\%

24 Ibidem.

25 Ibidem.

26 Polacy dobrze oceniaja członkostwo w UE, „Newsweek”, http://spoleczenstwo.newsweek.pl/sondaz-polacy-dobrze-oceniaja-czlonkostwo-w-ue,88443,1,1.html, 15.06.2012.

27 W. Fehler, Bezpieczeństwo wewnętrzne kraju, Warszawa 2010, s. 68, http://www.mrr.gov.pl/ rozwoj_regionalny/Polityka_rozwoju/SRK/Ekspertyzy_aktualizacja_SRK_1010/Documents/bezpieczenstwo_wewnetrzne_panstwa_2010.pdf, 12.06.2012. 
respondentów wyraziło opinię, iż Polska nie jest krajem, w którym żyje się bezpiecznie, a w najbliższym roku, nic w tym zakresie się nie zmieni. I tak też okazało się w rzeczywistości, mianowicie z sondażu CBOS wynika, że rok 2001 był okresem największego negatywnego poczucia bezpieczeństwa. Może się to wiązać $\mathrm{z}$ atakami terrorystycznymi na World Trade Center i samą zmianą teorii bezpieczeństwa. Zmiany nastapiły w latach 2002-2005, a dopiero w 2007 r. odnotowano, że Polska jest krajem, w którym można czuć się bezpiecznie $^{28}$. Zbiega się to z czasem akcesji Polski do Unii Europejskiej.

\section{Korzyści i koszty czlonkostwa w Unii Europejskiej}

Materiały rozprowadzane na terenie Polski przed referendum akcesyjnym to m.in. ulotki, przewodniki i informatory. Znajdowały się w nich informacje dotyczące korzyści wstapienia Polski do UE. Informatory te zawierały informacje głównie wskazujące na korzyści, celowo natomiast pomijane były te spotykające się z brakiem akceptacji społecznej. W ulotce Kilka słów o Unii Europejskiej ${ }^{29}$, przeczytać można było, że Unia stwarza niepowtarzalne szanse rozwoju Polski, członkostwo w niej wzmocni pozycję Polski na arenie międzynarodowej, a także zapewni wyższe poczucie bezpieczeństwa. UKIE deklarowało również zlikwidowanie różnic rozwojowych między naszym krajem a dotychczasową piętnastką krajów członkowskich. Kolejną wymienianą w ulotce informacyjnej korzyścią było włączenie Polski do obszaru swobodnego przepływu towarów, usług, kapitału i osób. Obecność naszego kraju w strukturach Unijnych miałaby również gwarantować zwiększenie ilości zagranicznych inwestycji w Polsce, a także możliwość podejmowania pracy za granica. Mnożyły się zachęty, natomiast o ewentualnych konsekwencjach lub kosztach przystapienia do UE nie wspominano. Tak samo w informatorach, nie znajdowały się informacje dotyczące chociażby konieczności, w dłuższej perspektywie czasowej, przyjęcia wspólnej waluty Euro. Wśród osób głosujących w referendum akcesyjnym za wstąpieniem Polski do UE często zdarzały się jednostki, które nie były świadome konieczności przyjęcia wspólnej waluty. Znaczna część społeczeństwa w obecnej sytuacji, szczególnie biorąc pod uwagę przykład Grecji, nie chce wstąpienia Polski do strefy euro ${ }^{30}$. Zastanowić się można by było, czy taka wiedza miała by znaczący wpływ na decyzję społeczeństwa w 2003 roku.

Materiały wskazujące wyłącznie na korzyści członkostwa w UE z punktu widzenia interesantów stają się mniej wiarygodne, aczkolwiek skłaniają do podświadomej refleksji. Interesant w konsekwencji ma większe szanse by dojść do wniosku, że członkostwo w UE będzie dla niego korzystne. Kampania informacyjna, jak się zdaje, miała charakter wysoce polityczny. Wykazywała się pomijaniem informacji mogących zrazić społeczeństwo do podjęcia decyzji o głosowaniu za wstapieniem Polski do UE. Zabieg ten zdaje się być logicznym, szczególnie biorąc pod uwagę fakt, iż stanowiło to wówczas najważniejszy cel polityczny naszego kraju. Do pomijanych informacji można np. zali-

28 Ibidem.

29 Ulotka wydana przez Urząd Komitetu Integracji Europejskiej.

30 Analiza wypowiedzi na forach internetowych. 
czyć wspomnianą wyżej konieczność przyjęcia wspólnej waluty czy też utratę częściowej suwerenności kraju.

Analiza korzyści, jakie obecnie czerpią Polacy z rozwoju gospodarki rynkowej, wykazuje przede wszystkim, że są one wciąż udziałem nieznacznej części społeczeństwa polskiego. Powstaje układ stratyfikacji, której mechanizm jest generowany w wyniku zderzenia relatywnie nielicznych grup zdolnych korzystać z większych możliwości działania i osiagania szeroko rozumianego sukcesu życiowego, ze znacznie liczniejszymi grupami, które nadal nie potrafią wykorzystywać możliwości, które daje im Unia $^{31}$. Niemniej jednak korzyści z członkostwa w UE są widoczne, szczególnie gdy weźmie się pod uwagę liczbę inwestycji powstałych dzięki dofinansowaniom z Unii. Trzeba natomiast dodać, iż metodą prób i błędów, beneficjenci w Polsce, coraz częściej potrafią efektywnie wykorzystywać środki finansowe z Unii. Należy również zwrócić uwagę na szczególny nacisk działań w kierunku rozwoju obszarów wiejskich. W analizie strat trzeba także uwzględnić poniesione koszty dostosowania prawa polskiego i gospodarki do standardów unijnych, utratę suwerenności, a także koszty ponoszone w ramach ochrony środowiska dostosowanej do UE i ochrony granic wschodnich jako granic zewnętrznych UE. Najbardziej niekorzystnym zjawiskiem związanym z akcesją do UE i również najczęściej zauważanym przez społeczeństwo jest wzrost cen artykułów rolno-spożywczych ${ }^{32}$. Na koszty przystapienia do UE zwracały szczególnie uwage grupy eurosceptyczne wymieniając o wiele więcej wad członkostwa w UE ${ }^{33}$.

Nie mniej ważnym aspektem kosztów przystąpienia do UE jest współczesna, rozwijająca się refleksja na temat dalszej integracji europejskiej, a więc również ponoszenia w przyszłości kosztów przez Polskę na rzecz biedniejszych, rozwijających się krajów. Wśród społeczeństwa pojawiają się opinie, że Polska, w dłuższej perspektywie czasowej, więcej straci na członkostwie w UE niż zyska. Pojawiają się również obawy, że nikt nikomu nie pomaga bezinteresownie, a najbogatsze kraje UE pomagają Polsce, ponieważ mają w tym jakiś „tajny” interes ${ }^{34}$. Takie opinie to jednak rzadkość.

\section{Wnioski}

Konkludując, nastroje polskiego społeczeństwa przed akcesją Polski do Unii Europejskiej nie były stabilne. Wyniki sondaży zmieniały się w poszczególnych miesiącach, podobnie jak oczekiwania, nadzieje i obawy Polaków związane z członkostwem w UE. Nastroje respondentów odzwierciedlały w większości ich status społeczno-zawodowy. Kampania informacyjna okazała się być skuteczną i przekonała większość obywateli o korzyściach jakie będą płynęły z członkostwa.

W tym okresie pojawiło się w Polsce wiele grup interesu agitujących za poparciem dla procesu integracji. Wśród samych partii politycznych zaobserwować można było

31 E. Skotnicka-Illasiewicz (red.), Społeczny bilans..., op. cit., s. 115.

32 Przystapienie Polski do Unii europejskiej. Traktat akcesyjny i jego skutki, red. S. Biernat, S. Dudzik, M. Niedźwiedź, Kraków 2003, s. 91.

33 J. Barcz, E. Kawecka-Wyrzykowska, K. Michałowska-Gorywoda, Integracja..., op. cit., s. 215.

34 Analiza wypowiedzi na forach internetowych. 
antagonistyczne, a wręcz skrajne nastroje ewaluujące wciąż na chwilę przed akcesją. Jednakże zarówno media, jak i wszelkiego rodzaju organizacje pozarządowe oraz instytucje dokładały wszelkich starań, by odpowiednio poinformować społeczeństwo o korzyściach płynących ze wstapienia do struktur unijnych, zarówno na poziomie centralnym, regionalnym, jak i lokalnym, realizując tym samym główny cel rządowy. Wysiłki skierowane na przygotowanie społeczeństwa do członkostwa Polski w Unii Europejskiej można uznać za zadawalające. W perspektywie czasu można jednak zauważyć stosunkowo wysoki poziom lakoniczności przekazów informacyjnych oraz pomijanie informacji, związanych z kosztami, jakie Polska mogłaby ponieść w związku z przystapieniem do UE. Owa lakoniczność wynikała zapewne z chęci uproszczenia odbiorcy rozumienia istoty UE, a pomijanie wybranych konsekwencji członkostwa Polski w UE zapewne miało charakter celowy, by skutecznie zrealizować cel rządowy, jakim było wstapienie Polski do UE.

Z aktualnych badań sondażowych wnioskować można, iż Polacy w znacznej większości pozytywnie oceniają proces integracji, jak i samo przystąpienie Polski do Unii Europejskiej, a społeczeństwo wykazało się zadawalającym poziomem zaangażowania politycznego. Zaobserwować można było również sekwencję działań związanych z argumentacją swoich przekonań na temat UE przez znaczących aktorów politycznych. Niemniej jednak w społeczeństwie polskim panuje wspólne przeświadczenie o drugorzędnej roli Polski w strukturach unijnych, aczkolwiek podjęcie decyzji o członkostwie w UE zdaje się być uważane przez obywateli za korzystne. Wraz z akcesją Polski do UE miał miejsce również wzrost obywatelskiego poczucia bezpieczeństwa i stabilności kraju.

\section{Summary}

Political culture and the level of awareness of Polish society as well as the role of political commitment in the light of Polish accession to the European Union

The prospect of Poland's joining the EU stirred various emotions and triggered a series of purposeful activities carried out in many dimensions and in numerous areas. Both those at the national and local level were supposed to prepare Poles well for this move. Another desirable outcome concerned the increased political commitment and awareness of Polish society. Even though, in the initial period of negotiations, Poles clearly mistrusted the government and the activity of individual persons, a clear majority were in favor of accession to the EU in the final vote. The political activity and commitment of Polish society advantageously impacted on the level of political culture at that time. The downside involved a profound and distinct division into the supporters and opponents of the accession, both in the media and among political parties. 
